\title{
Socio-Economic Status and Rearing Practices of Tribal Goat Farmers in Attappadi Hills of Kerala, India
}

\author{
R. Thirupathy Venkatachalapathy ${ }^{1 *}$, Safeer M. Saifudeen ${ }^{2}$, \\ V. Vishnu Savanth ${ }^{2}$, LasnaSahib ${ }^{3}$ and S. Pramod ${ }^{3}$
}

Indian Council of Agricultural Research-All India Co-ordinated Research Project on Goat Improvement (Malabari), Centre for Advanced Studies in Animal Genetics and Breeding, Kerala Veterinary and Animal Sciences University, Thrissur-680651, India

*Corresponding author

\section{A B S T R A C T}

Keywords

Attappadi black, Tribal community, Goat farmers, Rearing pattern, Socio-economic status

Article Info

Accepted:

14 June 2020 Available Online: 10 July 2020
The present study was conducted to assess the goat rearing pattern and socio personal status of tribal farmers in Attappadi region of Kerala. Results indicated that about 20 per cent of tribal farmers were landless while 45 per cent of them owned less than an acre of land and the rest (about 35\%) owned more than an acre of land. Majority (61.27\%) of the goat farmers of Attappadi region were illiterate, unlike among other regions of the state, where literacy generally exceeds 90 per cent. Nearly 70 per cent of the flocks were composed of 6-15 animals. Animal housing facilities were severely limited and $41.70 \%$ of farmers opted for the extensive production system. The nutritional requirements of the goat were met by adjusting the grazing hours depending upon the season. There was a positive correlation between total goats reared by farmers and total land owned by them $(\mathrm{r}$ $\left.=0.175^{*}\right)$. As the flock size increased, the number of grazing hours also increased $\left(\mathrm{r}=0.223^{*}\right)$. There was a negative correlation between total goats reared by farmers and the deworming status of goats $(\mathrm{r}=-0.187 * *)$. A negative correlation between total land owned by farmers and housing facilities provided to goats $(\mathrm{r}=$ $0.181^{* *}$ ) was observed.

\section{Introduction}

The study was carried out at Attappadi block in the Palakkad district of Kerala. The block spans over an area of $745 \mathrm{sq} . \mathrm{km}$ and includes three Panchayats namely Agali, Puthur and Sholayur. It is subdivided into 6 revenue villages namely, Padavayal, Pudur,
Kottathara, Agali, Sholayur and Kallamala. Attappadi, which had a tribal population of 90 percent in 1951, is now at 35 percent after immigration of people from eastern Tamil Nadu and western Kerala side. The tribals who maintained a self-sufficient subsistence economy, life support natural systems as well as ecologically harmonious lifestyle were 
severely affected after the influx of outside communities who brought with them their own cultural values and agricultural practices. They lost their collectively owned land and became homeless and disempowered. Their cultural as well as unique agricultural foundations were totally destroyed and devalued (Report of Attappadi Comprehensive Tribal Development and Particularly Vulnerable Tribal Group Development Project).

The living pattern of the tribals is highly interconnected with the forest. Tribals, mainly based on their community, are cultivators of crops or are gathering community, who collect forest produce for their livelihood. Some of them also rear livestock like cattle, goat, sheep etc., most of which they lost access due to displacement, limiting their modes of sustenance (Joseph and Beegom, 2017).

Even though a lot of projects for upliftment of the community have been executed, the impact has been limited. A study by Vineetha et al., 2018, recommends encouragement of farming activities especially at the household level to increase livelihood opportunities and to ensure health of tribal groups in Attappadi instead of large-scale operations. The tribals of Attappadi region have been rearing goats on a zero input system, based on community grazing, since long, which has led to the development of a recognized goat breed of Kerala, the Attappadi Black. Attapady Black goats are very hardy in nature and can survive in the harsh climates and maintain a subsistence level production (Raja, 2014). The goats were primarily reared for meat and manure purposes. These goats have excellent immunity to most of the diseases and can survive under fairly simple and extensive production system with a low level of managerial skills (Aggarwal et al., 2006).
Attappadi Black goats are found exclusively in Attappadi and a survey on these goats carried out in the breeding tract revealed that it represented only $40 \%$ of the total goat population in the area (Stephen et al., 2005). The immigrated population had brought with them other breeds of goats and the community grazing system of rearing has led to the genetic dilution of the pure Attappadi Black goat in recent years.

This study was intended to observe the goat rearing patterns of the tribals of Attappadi and its relation to the age, education status, land holding etc.

\section{Materials and Methods}

A training on goat rearing was organized by ICAR-AICRP on $26^{\text {th }}$ and $27^{\text {th }}$ February, 2019 at Agali, Attappadi, engaging almost all the local farmers involved in goat rearing. In order to attract goat farmers of all communities, classes were arranged in local languages, Malayalam and Tamil. Mineral mixtures, dewormers and handouts on goat farming were distributed free of cost. All these ensured a participation of 264 farmers which formed a good base for the conduct of the survey to study the rearing pattern of goats in the Attappadi region.

Volunteers of the training met individual farmers at the venue, interacted with them and filled up a questionnaire prepared for the survey. Collected data were subjected to preliminary and descriptive analysis. Karl Pearson's co-efficient of correlation was used to find out the association between selected variables. Multiple linear regression was used to quantify the relationship between dependent and independent variables. Whole statistical analysis were done using IBM SPSS version 23. 


\section{Results and Discussion}

\section{Socio-economic status and rearing practices of farmers}

The socio-economic status of the farmers in Attappadi and its impact on goat rearing is explained in Table I. Among the 264 farmers surveyed, nearly $38 \%$ were above 45 years and $28.43 \%$ were under 36 years of age. One third of the people were of the age group 3645. The Survey indicated a healthy and even distribution of farmers in all age groups with a significantly high percentage of farmers less than 45 years of age. This trend is sparsely seen in other farming enterprises in Kerala. The special socio-cultural aspects of the zone were the main reason for the findings. A study by Bashir and Venkatachalapathy, 2017a identified $50.48 \%$ of goat farmers in the Malabari goats' native tract to be in the 31-50 years age group.

Kerala is ranked high in the literacy rate, and the goat farmers too are well educated in the Northern Kerala as per Bashir and Venkatachalapathy, 2017b who reported that nearly $92 \%$ of the heads of the families were educated and $15 \%$ of them had high school level education. However, in the field of this study, unfortunately, 61.27 percent people were illiterates. Thirty two percent people included in the study had upper primary education which was achieved by continous efforts of Government, NGO organizations and other volunteers. About one-fifth of the study group was landless farmers, depicting the important role played by goat husbandry sector as a means of livelihood in Attappadi area. 44.6 percentage of the sample population owned less than an acre of land and around $35 \%$ owned more than an acre of land.

The goat farmers of Attappadi considered a flock size of 6-15 goats as ideal and around
$70 \%$ of farmers followed that pattern. About $11.27 \%$ of the farmers had more than 15 goats in the study group. In the Northern Kerala, around $85 \%$ farmers had a flock size of just 46 goats (Bashir and Venkatachalapathy, 2017b), thus clearly showing the differences in the rearing pattern with the differences in the cultural and social background of the study group. The larger flock size indicates that this sector could be the source of primary income for the Attappadi farmers and just a source of supplementary income for the Northern Kerala participants. Animal housing facilities were severely limited and $41.70 \%$ of farmers opted for the extensive farming system. Remaining $58.30 \%$ of farmers provided housing facilities to their goats. Due to the poor economic status of the farmers, $70 \%$ of the goats did not receive concentrates at all. The nutritional requirements of the goat were met by adjusting the grazing hours depending upon the season. The evolution of Attappadi black as a hardy breed, with subsistence level production is a result of selection happening in this type of rearing environment.

The hardy nature of the breed Attappadi black comes to the forefront with the evidence that vaccination was rarely carried out in the region with a mere $6.4 \%$ of the animals being vaccinated. Deworming status was a little better with around one third of the animals being administered dewormers. Ninety-three percentage of the participants claimed to have not attended any scientific training programmes on goats. The prospect of providing training on scientific rearing practices suited to their style of rearing and the scope of generating additional income to improve their livelihood can be looked forward to in the future upliftment projects. The residents' interest in goat farming, which is part of their culture should be maintained and promoted for their own betterment and for the conservation of Attappadi black goat, 
which may have valuable information to be offered to the scientific community.

\section{Correlation between socio-economic aspects and activities of goat farmers}

Strength of association between two selected variables and the direction of the relationship was measured using Karl Pearson's bivariate correlation. Table II showed various results for bivariate correlations. There was a positive correlation between total goats reared by farmers and total land owned by them ( $\mathrm{r}=$ $\left.0.175^{*}\right)$. It was clear that farmers having more land were willing to rear higher number of goats. Highly positive correlation could be observed in the case of total goats reared and the number of Attappadi black goats. Larger the herd strength, higher the proportion of Attappadi black among them $\left(\mathrm{r}=0.713^{* *}\right)$.

As the flock size increased, the number of grazing hours also increased $(\mathrm{r}=0.223 * *)$. The farmers with larger flock considered it as their primary source of income and were willing to invest more time for it. It was clear that farmers depend more on grazing to maintain their animals as concentrate feeding was very insignificant. It can also be looked upon as farmers owning more land or the farmers who were able to graze their animals were willing to rear higher number of goats.

Table.1 Socio-economic status and rearing practices of the tribal goat farmers in Attappadi hills

\begin{tabular}{|c|c|c|c|c|}
\hline Sl.No. & Category & Classification & Count & Percentage \\
\hline \multirow[t]{3}{*}{$\mathbf{1}$} & \multirow[t]{3}{*}{ Age } & Upto 35 & 75 & 28.43 \\
\hline & & $36-45$ & 88 & 33.33 \\
\hline & & Above 45 & 101 & 38.24 \\
\hline \multirow[t]{4}{*}{2} & \multirow[t]{4}{*}{ Education } & Illiterate & 162 & 61.27 \\
\hline & & Lower primary & 18 & 6.90 \\
\hline & & Upper primary & 48 & 18.14 \\
\hline & & High School & 36 & 13.73 \\
\hline \multirow[t]{4}{*}{3} & \multirow[t]{4}{*}{ Land holding } & Landless & 53 & 20.10 \\
\hline & & Up to 1 acre & 118 & 44.61 \\
\hline & & 1-2 acre & 44 & 16.67 \\
\hline & & Greater than 2 acre & 49 & 18.63 \\
\hline \multirow[t]{4}{*}{4} & \multirow[t]{4}{*}{ Flock Size } & $1-2$ & 14 & 5.39 \\
\hline & & $3-5$ & 35 & 13.24 \\
\hline & & $6-15$ & 185 & 70.10 \\
\hline & & Above 15 & 30 & 11.27 \\
\hline \multirow[t]{2}{*}{5} & \multirow{2}{*}{$\begin{array}{l}\text { Provision of } \\
\text { Housing }\end{array}$} & Yes & 154 & 58.30 \\
\hline & & No & 110 & 41.70 \\
\hline \multirow[t]{2}{*}{6} & \multirow{2}{*}{$\begin{array}{l}\text { Concentrate } \\
\text { feeding }\end{array}$} & Yes & 80 & 30.40 \\
\hline & & No & 184 & 69.60 \\
\hline \multirow[t]{2}{*}{7} & \multirow{2}{*}{$\begin{array}{l}\text { Vaccination } \\
\text { Status }\end{array}$} & Yes & 17 & 6.40 \\
\hline & & No & 247 & 93.60 \\
\hline \multirow[t]{2}{*}{8} & \multirow{2}{*}{$\begin{array}{l}\text { Deworming } \\
\text { Status }\end{array}$} & Yes & 88 & 33.30 \\
\hline & & No & 176 & 66.70 \\
\hline \multirow[t]{2}{*}{9} & \multirow{2}{*}{$\begin{array}{c}\text { Farmers attended } \\
\text { training } \\
\text { previously }\end{array}$} & Yes & 18 & 6.90 \\
\hline & & No & 246 & 93.10 \\
\hline
\end{tabular}


Table.2 Bivariate correlation between different socioeconomic aspects and activities of goat farmers in Attappadi

\begin{tabular}{|l|l|l|c|c|}
\hline $\begin{array}{l}\text { Sl. } \\
\text { No. }\end{array}$ & First Variable & Second Variable & $\begin{array}{c}\text { Karl Pearson's } \\
\text { correlation } \\
\text { coefficient (r) }\end{array}$ & Sig \\
\hline $\mathbf{1}$ & Total goats reared & Total land owned & $0.175^{*}$ & 0.012 \\
\hline $\mathbf{2}$ & Total goats reared & Attappadi goats reared & $0.713^{* *}$ & 0.000 \\
\hline $\mathbf{3}$ & Total goats reared & Total hours for grazing & $0.223^{* *}$ & 0.001 \\
\hline $\mathbf{4}$ & Total goats reared & Deworming status & $-0.187^{* *}$ & 0.007 \\
\hline $\mathbf{5}$ & Total goats reared & Concentrate feed supply & $-0.069^{\text {NS }}$ & 0.324 \\
\hline $\mathbf{6}$ & Attappadi goats reared & Concentrate feed supply & $-0.149^{*}$ & 0.03 \\
\hline $\mathbf{7}$ & Total land owned & Housing facilities provided & $-0.181^{* *}$ & 0.009 \\
\hline $\mathbf{8}$ & Educational qualification & Attappadi goats reared & $0.141^{*}$ & 0.04 \\
\hline $\mathbf{9}$ & Educational qualification & Training programs attended & $0.166^{*}$ & 0.018 \\
\hline $\mathbf{1 0}$ & Educational qualification & Age of farmers & $-0.432^{* *}$ & 0.000 \\
\hline $\mathbf{1 1}$ & Housing facilities provided & Age of farmers & $-0.176^{*}$ & 0.012 \\
\hline **. Correlation is significant at the 0.01 level (2-tailed) & & \\
\hline *. Correlation is significant at the 0.05 level (2-tailed) & & \\
\hline
\end{tabular}

Table.3 Multiple regression analysis

\begin{tabular}{|l|c|c|c|}
\hline \multirow{2}{*}{ Independent variables } & \multicolumn{2}{|c|}{ Unstandardized Coefficients } & \multirow{2}{*}{ Sig. } \\
\cline { 2 - 4 } & $\mathbf{B}$ & Std. Error & \\
\hline (Constant) & 2.414 & 1.848 & .193 \\
\hline Age of farmers & .041 & .023 & .081 \\
\hline Educational qualification & -.443 & .259 & .089 \\
\hline Total land owned & .003 & .002 & .170 \\
\hline Total Attappadi goats reared & $\mathbf{. 5 9 1}$ & $\mathbf{. 0 4 3}$ & $\mathbf{. 0 0 0}$ \\
\hline Total grazing hours & $\mathbf{. 4 2 6}$ & $\mathbf{. 1 8 1}$ & $\mathbf{. 0 1 9}$ \\
\hline Housing provided & .325 & .582 & .578 \\
\hline R Square - 0.551 & \multicolumn{3}{|c|}{ F value - $40.049^{* *}$} \\
\hline Dependant variable - Total number of goats reared \\
\hline
\end{tabular}

There was a negative correlation between total goats reared by farmers and the deworming status of goats $\left(\mathrm{r}=-0.187^{* *}\right)$. Farmers with a greater number of goats probably preferred an extensive rearing system and coupled with the lack of knowledge about scientific rearing practices, deworming lacked penetration.

We were not able to find any significant correlation between total number of goats reared and concentrate feeding to goats. One interesting thing noted was that a negative correlation existed between number of Attappadi black goats reared and concentrate feed supplied to goats. Farmers rearing greater number of Attappadi black goats were less interested in concentrate feeding. Rather, they preferred alternative feeding methods like grazing.

A negative correlation between total land 
owned by farmers and housing facilities provided to goats $(\mathrm{r}=-0.181 * *)$ was observed. Farmers with more land opted to graze their animals extensively. Farmers with less land confined their animals within housing facilities. The educational qualification of the farmer had an effect on the preference for the goat breed with farmers having comparatively higher education opting for Attappadi black goats $\left(\mathrm{r}=0.141^{*}\right)$. People who attended scientific training programmes on goat rearing were more from the better educated group $\left(r=0.166^{*}\right)$, stressing the importance of education, irrespective of the field of application.

As expected, the aged farmers were less educationally qualified $(\mathrm{r}=-0.432 * *)$. Another negative correlation was observed between age of farmers and housing facilities provided by the farmers to the goats $(r=-$ $\left.0.176^{*}\right)$.This might be due to the traditional practice of rearing Attappadi black goats by extensive system.

\section{Multiple regression analysis}

Multiple Linear Regression was used to explain the relationship between one continuous dependent variable and two or more independent variables. This statistical tool was used in the present study with dependent variable being 'total number of goats reared'. From the Table III, it is clear that out of the six different independent variables used, the statistically significant variables were 'total Attappadi black goats reared' and 'total grazing hours'. The $\mathrm{R}^{2}$ value for the study is 0.551 which means that $55.1 \%$ information about dependent variables is obtained from all the independent variables selected. The regression model was found significant at one percent level of significance $(\mathrm{F}$ value $=40.049 * *)$
Results explained that unit increase in Attappadi black goat reared by farmers caused an increase of 0.59 unit in total number of goats reared. In the case of total grazing hours, it was revealed that provision of increase in one hour of grazing for the goats caused an overall increase of 0.43 units in total goats reared. The farmers are confident with rearing bigger flocks when they have higher percentage of Attappadi black goats. The availability of grazing land also helps the farmer to maintain bigger flocks.

From the study it can be concluded that about 20 per cent of tribal farmers were landless, with majority (61.27\%) of the goat farmers of Attappadi region being illiterate. About 42 per cent of the farmers did not provide any housing for the goats. The goats were mostly dependent on grazing for nutrition since 70 percent of the goats did not receive concentrate feeds. These limitations are amenable for intervention by government agencies. Most of the herds were composed of 6-15 goats. Significant positive correlation was observed between area of land owned and number of goats reared. Flock and the number of grazing hours were also positively correlated. Significant negative correlations were observed between total goats reared by farmers and the deworming status of goats as well as between total land owned by farmers and housing facilities provided to goats.

\section{Acknowledgements}

The authors thank All India Coordinated Research Project (AICRP) on Goat Improvement and the Kerala Veterinary and Animal Sciences University for providing financial support and infrastructure facilities required for the conduct of research work. 


\section{References}

Aggarwal, R.A.K., Dixit, S.P., Verma, N.K., Mathew, S., Kumar, D., Ahlawat, S.P.S., Kumar, S. and Kumar, Y. 2006. Genetic diversity in Attappady breed of Indian goat as analyzed with microsatellite markers. Korean Journal of Genetics, 28: 237-242.

Bashir, B.P. and Venkatachalapathy, R.T. 2017a. Rearing systems of Malabari goats in Northern Kerala, India. Indian Journal of Small Ruminants 23: 248252.

Bashir, B.P. and Venkatachalapathy, R.T. 2017b. Study on supply chains of goats in northern Kerala. Advances in Animal and Veterinary Sciences 5: 395-399.

Joseph, A. and Beegom, R.K. 2017. Cultural Genocide among Tribals: An Excrescence of Development Induced Displacement. Journal of Multidisciplinary Studies in Archaeology 5: 620- 630.

Kamalakkannan, R., Jose, J., Thomas, S.,
Prabhu, V.R. and Nagarajan, M. 2018. Genetic diversity and maternal lineages of south Indian goats. Molecular Biology Reports, 45: 2741-2748.

Raja, T.V. 2014. Study on certain non-genetic factors affecting birth weight of Attappady Black goats. Research Journal of Animal Sciences8: 1-3.

Report of Attappady Comprehensive Tribal Development and Particularly Vulnerable Tribal Group Development Project. 2019. P 27.

Stephen, M., Raja, T.V. and Sosamma, I. 2005. Survey and characterization of Attappady black goats of Kerala, India. Animal Genetic Resources37: 4352.

Vineetha, P.G., Sarath, M., Babu, B.A., Cyriac, S. and Nisamol, M.A. 2018. A survey on scope of poultry farming as livelihood in Attappadi tribal settlements with special reference to Agalipanchayat-Kerala. Indian Veterinary Journal 95: 23-25.

\section{How to cite this article:}

Thirupathy Venkatachalapathy, R., Safeer M. Saifudeen, V. Vishnu Savanth, Lasna Sahib and Pramod, S. 2020. Socio-Economic Status and Rearing Practices of Tribal Goat Farmers in Attappadi Hills of Kerala, India. Int.J.Curr.Microbiol.App.Sci. 9(07): 1341-1347.

doi: https://doi.org/10.20546/ijcmas.2020.907.155 